\title{
Novel Coated Wires Sensors with Flow-Injection for Potentiometric Determination of Neostigmine in Bulk, Amostigmine and Human Urine
}

\section{Khorshid $\mathrm{AF}^{1 *}$ and Issa $\mathrm{YM}^{2}$}

${ }^{1}$ Pharmaceutical Analytical Chemistry department, Faculty of Pharmacy, Nahda University, NUB, New Beni-Sueff, Egypt

${ }^{2}$ Chemistry Department, Faculty of Science, Cairo University, Egypt

\begin{abstract}
Four types of coated wires sensors (silver, copper, graphite and glassy carbon) are constructed for the determination of neostigmine (Ns) based on the ion-pair associates neostigmine silicotungstate (Ns-ST), neostigmine silicomolybdate (Ns-SM), neostigmine phosphotungstate (Ns-PT), neostigmine phospho molybdate (Ns-PM),and ion-pairs neostigmine tetraphenylborate (Ns-TPB) in a poly (vinyl chloride) as coated film with a plasticized tricresylphthalate (TCP). The four types sensors are showed a Nernstain slopes ranged from 59-64 mV per decade in batch and 65-70 $\mathrm{mV}$ per decade in flow injection conditions (FIA) over a neostigmine concentration ranged from $5.0 \times 10^{-7}-1.0 \times 10^{-2} \mathrm{M}$ and within the $\mathrm{pH}$ range 4.0-11.0. The influences of coated film composition, $\mathrm{pH}$ of the Ns and foreign ions on the sensors performance were investigated and were found to be very selective, precise and excellent selectivity. The sensors were successfully applied to the potentiometric determination of neostigmine bromide in pure state, in amostigmine, and human urine. FI analysis and dissolution profile for determination neostigmine were investigated. The data were comparable with official methods for the assay and excellent percentage recovery was obtained.
\end{abstract}

Keywords: Coated wire sensors; Ion pair; Neostigmine determination; Amostigmine; Flow injection analysis; Dissolution profile; Potentiometry

\section{Introduction}

Neostigmine Bromide [114-80-7] is [3-(dimethyl carbamoyloxy)$\mathrm{N}, \mathrm{N}, \mathrm{N}$ trimethylanilinium bromide with white crystalline powder or colorless crystals, hygroscopic, very soluble in water, freely soluble in alcohol and empirical formula $\mathrm{C} 12 \mathrm{H}_{1} 9 \mathrm{BrN}_{2} \mathrm{O}_{2}$ (mol. wt. 303.2) $[1,2]$. The main advantage for the fabrication of the coated wires sensors is no need for the inner electrolyte solution as the liquid membrane sensor beside its high dynamic range. The sensors are simply designed and consists of conductive bed coated with a coating mixture that containing an electro-active material.

This work describes new selective coated wires sensors type, for the determination of neostigmine in pure state, pharmaceutical dosage form, human urine, and flow injection analysis and dissolution profile. No coated wires sensors for the determination of neostigmine bromide are available in the literature survey [3-6] (Figure 1).

Our aim of the work is to develop, constructed and fabricated new types with the performance characteristics of the proposed coated wires sensors (CWS) that is one important type of membrane ionselective electrodes (ISEs) which used in pharmaceutical and biological analysis [7-14]. This is due to easy in work, simple in their design, good accuracy, low cost and can be hold without the inner solution as liquid membrane which may be contaminated, wide concentration range and applicability to turbid and colored solutions.

\section{Experimental}

\section{Materials and methods}

All reagents used were chemically pure grade. Doubly distilled water was used. Neostigmine bromide and its pharmaceutical preparation Amostigmine [(tablets and injection) (15 mg/tablet), $(0.5$ $\mathrm{mg} / \mathrm{mL})$ ] respectively, were provided by Amoun Pharmaceutical Co., Cairo, Egypt)
Poly vinyl chloride (PVC), tricresyl phthalate (TCP), tetrahydrofuran (THF), silicotungestic acid (STA), silicomolybdic acid (SMA), phosphotungestic acid (PTA), phosphomolybdic acid (PMA) and sodium tetraphenylborate (NaTPB) were selective products from Aldrich. In FIA measurements, the reagent and carrier solutions were degassed to remove air bubbles which may influence the sensitivity of the sensor potential or the carrier flow solution by means of vacuumsuction.

\section{Preparation of ion-exchangers}

For the preparation of ion-exchangers, neostigmine silicotungstate (Ns-ST $)_{4}$, neostigmine silicomolybdate (Ns-SM $)_{4}$, neostigmine phosphotungstate (Ns- $\mathrm{PT}_{3}$ ), neostigmine phosphomolybdate (Ns$\mathrm{PM}_{3}$ ), and neostigmine tetraphenylborate (Ns-TPB), were prepared

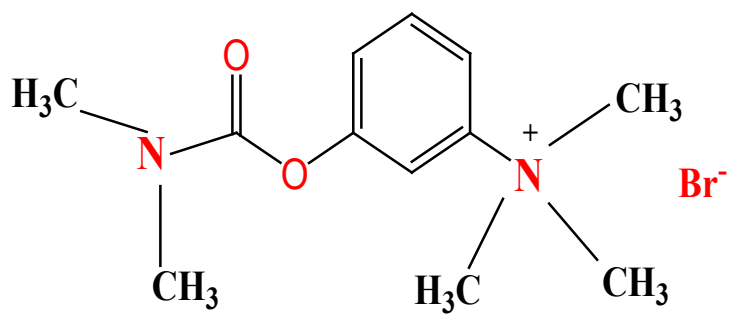

Figure 1: The chemical structure of neostigmine bromide.

*Corresponding author: Khorshid AF, Pharmaceutical Analytical Chemistry department, Faculty of Pharmacy, Nahda University, NUB, New Beni-Sueff, Egypt, Tel: +2082-2284680; E-mail: amalkorshid@yahoo.com

Received March 20, 2015; Accepted April 13, 2015; Published April 27, 2015

Citation: Khorshid AF, Issa YM (2015) Novel Coated Wires Sensors with FlowInjection for Potentiometric Determination of Neostigmine in Bulk. Amostigmine and Human Urine. J Bioequiv Availab 7: 131-139. doi:10.4172/jbb.1000227

Copyright: (c) 2015 Khorshid AF, et al. This is an open-access article distributed under the terms of the Creative Commons Attribution License, which permits unrestricted use, distribution, and reproduction in any medium, provided the original author and source are credited. 
Citation: Khorshid AF, Issa YM (2015) Novel Coated Wires Sensors with Flow-Injection for Potentiometric Determination of Neostigmine in Bulk, Amostigmine and Human Urine. J Bioequiv Availab 7: 131-139. doi:10.4172/jbb.1000227

by adding $100 \mathrm{ml}$ of $10^{-2} \mathrm{M}$ neostigmine bromide (NsBr) solution to $100 \mathrm{ml}$ of equivalent solution of $2.5 \times 10^{-4} \mathrm{M}$ [(STA), (SMA)], $3.3 \times 10$ ${ }^{3} \mathrm{M}$ of [(PTA), (PMA)], and $1.0 \times 10^{-2} \mathrm{M}$ of (NaTPB). The precipitates were formed, filtered off, washed thoroughly with distilled water then dried at room temperature and ground to fine powder. The ion-pairs formation and purity of the ion-associates, chemical compositions of the precipitates were checked by elemental analysis for carbon, hydrogen and nitrogen at the Micro Analytical center, Cairo University. Results are given in Table 1.

\section{Construction of sensors}

Pure silver, copper, graphite and glassy carbon rods of $12 \mathrm{~cm}$ in length and $1 \mathrm{~mm}$ diameter were insulated by tight polyethylene tubes leaving $0.5 \mathrm{~cm}$ at one end for connection and at the other end $2 \mathrm{~cm}$ for coating. The coating solutions were prepared by dissolving varying certain amounts of ion-exchanger in the minimum possible amount of tetrahydrofuran $(2-3 \mathrm{ml})$ with powdered PVC and tricresylphthalate (TCP) as plasticizer. Before coating, the polished surface of the rods was washed with rinsed water and detergent, and then dried with acetone. The polished surface of each type of the rod was coated with the active membrane by dipping ( $2 \mathrm{~cm}$ for coating) of the exposed end into the coating solution then the film left for about three min on the each wire to dry. By repeated several times the process until a coated plastic membrane of approximately $1.0 \mathrm{~mm}$ thickness was formed. The prepared CW sensors were ready by soaking them for about thirty min in $1 \times 10^{-3} \mathrm{M}$ solution of the Ns drug.

\section{Apparatus}

The potentiometric measurements same as pervious discussed in research before [6].

\section{Recommended procedures}

Construction of the calibration graphs: $\mathrm{CW}$ membranes of different compositions were prepared. The percentages of each ionpairs association were changed to cover the ranges of $0.5-5 \%$, Ns (ST, SM, PT, PM and TPB) for each rod (silver, copper, graphite and glassy carbon) presented in Table 2. Suitable increments of standard $\mathrm{NsBr}$ solution were added to $50 \mathrm{ml}$ of doubly distilled water to cover the concentration range from $1.0 \times 10^{-7}$ to $1.0 \times 10^{-2} \mathrm{M}$. The concentration of unknown was determined from the calibration graph.

For FIA measurements, a series of freshly prepared solutions of the drug covering the range $1.0 \times 10^{-7}-1.0 \times 10^{-1} \mathrm{M}$ was injected to the flow stream and the corresponding peak heights were recorded and used to draw the calibration graphs.

Effect of soaking on life span of the sensor: In order to investigate the CW membrane life span, the CW sensor was soaked in $10^{-3} \mathrm{M}$ $\mathrm{NsBr}$ drug solution at $25^{\circ} \mathrm{C}$. The construction of calibration graph was built for each sensor after different time intervals covering the range from thirty min up to more than one month for each wire. Stop the measurements when the slope of the Nernstian value for calibration graph deviated largely where the sensor recovery was became out of range.

The regeneration was examined for the sensor by freshly reformation of the ion-association on the external CW membrane. The regeneration of the Ns CW membrane sensors was successfully achieved by soaking the exhausted sensor(s) for about $24 \mathrm{~h}$ in a $1.0 \times 10^{-2}$ M STA, SMA, PTA, PMA and/or NaTPB solution, followed by soaking in $1.0 \times 10^{-2} \mathrm{M} \mathrm{NsBr}$ drug solution for about $3 \mathrm{~h}$.

\section{Effect of $\mathrm{pH}$}

The effect of $\mathrm{pH}$ for the Ns drug test solution on the potential values of the sensor system in different concentrations $\left(1.0 \times 10^{-3}, 1.0 \times 10^{-4}\right.$ and $1.0 \times 10^{-5} \mathrm{M}$ ) of the drug was studied. In $100 \mathrm{ml}$ titration cell, aliquots of the Ns solution $(50 \mathrm{ml})$ were added and the tested ion-selective sensor in conjunction with the calomel reference sensor with a combined glass $\mathrm{C} \% \mathrm{H} \% \mathrm{~N} \%$

\begin{tabular}{|c|c|c|c|c|c|c|c|}
\hline lon-associate & Tentative Formulae & Calc. & Found & Calc. & Found & Calc. & Found \\
\hline $\mathrm{Ns} \mathrm{ST}_{4}$ (white) & {$\left[\mathrm{C}_{12} \mathrm{H}_{19} \mathrm{~N}_{2} \mathrm{O}_{2}\right]\left[\mathrm{SiW}_{12} \mathrm{O}_{40}\right]_{4}$} & 18.57 & 18.00 & 2.45 & 2.65 & 3.61 & 3.50 \\
\hline $\mathrm{Ns} \mathrm{SM}_{4}$ (f.yellow) & {$\left[\mathrm{C}_{12} \mathrm{H}_{19} \mathrm{~N}_{2} \mathrm{O}_{2}\right]\left[\mathrm{SiMo}_{12} \mathrm{O}_{40}\right]_{4}$} & 28.19 & 27.65 & 3.72 & 3.55 & 5.48 & 5.40 \\
\hline Ns-PT ${ }_{3}$ (buff) & {$\left[\mathrm{C}_{12} \mathrm{H}_{19} \mathrm{~N}_{2} \mathrm{O}_{2}\right]\left[\mathrm{PW}_{12} \mathrm{O}_{40}\right]_{3}$} & 12.17 & 11.83 & 1.60 & 1.55 & 2.36 & 2.30 \\
\hline Ns- $\mathrm{PM}_{3}$ (g.yellow ) & {$\left[\mathrm{C}_{12} \mathrm{H}_{19} \mathrm{~N}_{2} \mathrm{O}_{2}\right]\left[\mathrm{PMO}_{12} \mathrm{O}_{40}\right]_{3}$} & 21.12 & 20.78 & 2.79 & 2.48 & 4.11 & 3.92 \\
\hline Ns-TPB(white) & {$\left[\mathrm{C}_{12} \mathrm{H}_{19} \mathrm{~N}_{2} \mathrm{O}_{2}\right]\left[\mathrm{C}_{24} \mathrm{H}_{20} \mathrm{~B}\right]$} & 77.42 & 77.13 & 6.19 & 6.28 & 4.87 & 4.62 \\
\hline
\end{tabular}

Table 1: Elemental analyses of the ion-pairs.

\begin{tabular}{|c|c|c|c|c|c|c|c|c|c|}
\hline Sensors & I.P \% & $\begin{array}{l}\text { Linear range } \\
\text { (M) }\end{array}$ & $\begin{array}{c}\text { Slope } \\
\text { (mV/decade) }\end{array}$ & $t$ & Sensors & I.P \% & $\begin{array}{l}\text { Linear range } \\
\text { (M) }\end{array}$ & $\begin{array}{r}\text { Slope } \\
\text { (mV/decade) }\end{array}$ & $t$ \\
\hline \multicolumn{10}{|c|}{ Ag- CWECu-CWE } \\
\hline Ns-ST/Ag & 0.5 & $3.9 \times 10^{-7}-1.0 \times 10^{-2}$ & $59.5 \pm 0.5$ & $20 \mathrm{~d}$ & $\mathrm{Ns}-\mathrm{ST} / \mathrm{Cu}$ & 0.5 & $1.0 \times 10^{-6}-1.0 \times 10^{-2}$ & $57.5 \pm 0.5$ & $9 \mathrm{~d}$ \\
\hline $\mathrm{Ns}-\mathrm{SM} / \mathrm{Ag}$ & 1.0 & $6.3 \times 10^{-7}-1.0 \times 10^{-2}$ & $58.5 \pm 0.5$ & $15 \mathrm{~d}$ & Ns-SM/ Cu & 1.0 & $6.3 \times 10^{-7}-5.0 \times 10^{-3}$ & $56.5 \pm 0.5$ & $7 \mathrm{~d}$ \\
\hline Ns-PT/Ag & 1.0 & $5.0 \times 10^{-7}-1.0 \times 10^{-2}$ & $60.5 \pm 0.5$ & $27 \mathrm{~d}$ & Ns-PT/ Cu & 1.0 & $7.8 \times 10^{-7}-1.0 \times 10^{-2}$ & $58.5 \pm 0.5$ & $12 \mathrm{~d}$ \\
\hline $\mathrm{Ns}-\mathrm{PM} / \mathrm{Ag}$ & 2.5 & $3.5 \times 10^{-7}-1.0 \times 10^{-2}$ & $57.0 \pm 0.5$ & $12 \mathrm{~d}$ & Ns-PM/ Cu & 2.5 & $5.0 \times 10^{-7}-1.0 \times 10^{-2}$ & $57.0 \pm 0.5$ & $10 \mathrm{~d}$ \\
\hline Ns-TPB/Ag & 3.0 & $3.9 \times 10^{-7}-7.9 \times 10^{-3}$ & $57.5 \pm 0.5$ & $15 \mathrm{~d}$ & Ns-TPB/ Cu & 3.0 & $5.0 \times 10^{-6}-8.2 \times 10^{-3}$ & $57.5 \pm 0.5$ & $7 \mathrm{~d}$ \\
\hline \multicolumn{10}{|c|}{ Graphite-CWEGlassy carbon-CWE } \\
\hline Ns-ST/G & 0.5 & $7.9 \times 10^{-7}-1.0 \times 10^{-2}$ & $59.0 \pm 0.5$ & $18 \mathrm{~d}$ & Ns-ST/GC & 0.5 & $2.5 \times 10^{-7}-1.0 \times 10^{-2}$ & $59.5 \pm 0.5$ & $22 \mathrm{~d}$ \\
\hline Ns-SM/G & 1.0 & $6.3 \times 10^{-7}-5.0 \times 10^{-3}$ & $59.5 \pm 0.5$ & $17 \mathrm{~d}$ & Ns-SM/GC & 1.0 & $1.0 \times 10^{-7}-1.0 \times 10^{-2}$ & $59.5 \pm 0.5$ & $25 \mathrm{~d}$ \\
\hline Ns-PT/G & 1.0 & $5.8 \times 10^{-7}-1.0 \times 10^{-2}$ & $60.0 \pm 0.5$ & $23 \mathrm{~d}$ & Ns-PT/GC & 1.0 & $5.0 \times 10^{-8}-1.0 \times 10^{-2}$ & $60.5 \pm 0.5$ & $28 \mathrm{~d}$ \\
\hline Ns-PM/G & 2.5 & $5.0 \times 10^{-7}-1.0 \times 10^{-2}$ & $60.0 \pm 0.5$ & $15 \mathrm{~d}$ & Ns-PM/GC & 2.5 & $8.9 \times 10^{-8}-1.0 \times 10^{-2}$ & $61.0 \pm 0.5$ & $26 \mathrm{~d}$ \\
\hline Ns-TPB/G & 3.0 & $8.3 \times 10^{-7}-8.4 \times 10^{-3}$ & $58.5 \pm 0.5$ & $12 \mathrm{~d}$ & Ns-TPB/GC & 3.0 & $7.9 \times 10^{-7}-1.0 \times 10^{-2}$ & $58.5 \pm 0.5$ & $21 \mathrm{~d}$ \\
\hline
\end{tabular}

Where: PVC:TCP=1:1, $t$ : lifetime

Table 2: Response characteristics of Ag, Cu, graphiteand glassy carbon four different types coated CW sensors for $\mathrm{NsBr}$. 
Citation: Khorshid AF, Issa YM (2015) Novel Coated Wires Sensors with Flow-Injection for Potentiometric Determination of Neostigmine in Bulk, Amostigmine and Human Urine. J Bioequiv Availab 7: 131-139. doi:10.4172/jbb.1000227

sensor was immersed in the same solution. The change in $\mathrm{mV}$ with variation of $\mathrm{pH}$ readings was simultaneously recorded. The addition of very small volumes of $2 \mathrm{M} \mathrm{HCl}$ and/or (0.1-1.0 M) NaOH solution was responsible for variation of $\mathrm{pH}$ of the solution covering the range from 1.0-10.0. Construct the plot between $\mathrm{mV}$-readings against the $\mathrm{pH}$-values for the different concentrations.

\section{Selectivity of the sensor}

The determination of selectivity coefficients for different ionic species, sugars and amino acids for the sensors was studied by the matched potential methods (MPM) $[15,16]$, the potential of the drug $\left(\mathrm{a}_{\text {drug }}\right)$ in the range of $2.5 \times 10^{-4}-5.0 \times 10^{-5} \mathrm{M}$ were added to the reference solution and the corresponding potential change $(\Delta \mathrm{E})$ was recorded. As previously discussed in [6].

In FIA conditions the separate solution method [17] was used so first, the potential is measured in a solution containing known amount of the Ns, and second, the potential is measured in a solution containing the same concentration interfering ion. The selectivity values of $\log \mathrm{K}_{\mathrm{Ns}, \mathrm{J}^{I^{+}}}^{\mathrm{pot}}$ are calculated using the following equation:

$$
\log \mathrm{K}_{\mathrm{Ns}, \mathrm{J}^{\mathrm{z}}}^{\mathrm{pot}}=\frac{\mathrm{E}_{2}-\mathrm{E}_{1}}{\mathrm{~S}}+\log [\mathrm{Drug}]-\log \left[\mathrm{J}^{\mathrm{Z+}}\right]^{1 / \mathrm{z}}
$$

Where: $\mathrm{E}_{1}$ and $\mathrm{E}_{2}$ are the sensor potentials of $10^{-3} \mathrm{M}$ solution of each of the Nsdrug and interfering cation, $\mathrm{J}^{z+}$, respectively and $\mathrm{S}$ is the slope of the calibration graph.

\section{Potentiometric determination of $\mathrm{NsBr}$ by standard addition method}

The standard addition method was applied in batch measurements [15]. A known volume of standard $\mathrm{NsBr}$ solution is added to a cell containing $50 \mathrm{ml}$ water with different amounts of the Ns drug in its bulk, tablets and in spiked urine samples with known amounts of the drug. The reading in $\mathrm{mV}$ change was taken for each addition that used to calculate the concentration of the Ns in the sample solution using the following equation:

$$
C_{x}=C_{s}\left(\frac{V_{s}}{V_{x}+V_{s}}\right)\left(10^{n(\Delta E / S)}-\frac{V_{x}}{V_{s}+V_{x}}\right)^{-1}
$$

Where $C_{x}$ is the concentration to be determined, $V_{x}$ is the volume of the original sample solution, $\mathrm{V}_{\mathrm{s}}$ and $\mathrm{C}_{\mathrm{s}}$ are the volume and concentration of the standard solution added to the sample to be analyzed, respectively, $\Delta \mathrm{E}$ is the change in potential after addition of certain volume of standard solution, and $\mathrm{S}$ is the calibration graph slope.

\section{Determination of NsBr in Amostigmine tablets and injection}

The contents of 20 tablets amostigmine ( $15 \mathrm{mg} \mathrm{NsBr} /$ tablet) were weighed, powdered, and an accurately weighed portion (200-250 mg) was mixed with $25 \mathrm{ml}$ doubly distilled water, shaken for about thirty min in a mechanical shaker then filtered, the solution was completed to the mark with doubly distilled water and shaken. Taken different volumes of the native solution $(1.0-10 \mathrm{ml})$ and injected to the potentiometric determination.

In case of amostigmine injection $(0.5 \mathrm{mg} / \mathrm{ml})$ taken different volumes after mixing ten ampoules and preparing the injection for standard addition method determination.

\section{Determination of $\mathrm{NsBr}$ in spiked urine}

In spiked urine addition quantities of the Ns drug and five $\mathrm{ml}$ of urine were mixed to a volumetric flask, completed to the $100 \mathrm{ml}$ with doubly distilled water and adjust solutions of $\mathrm{pH}$ ranging from 4 to 5 by small addition of $0.01 \mathrm{M} \mathrm{HCl}$ from volume $(0.1-2 \mathrm{ml})$ and concentrations from $5.0 \times 10^{-6}$ to $2.5 \times 10^{-4} \mathrm{M}$ Ns. The standard addition method was used for drug determination.

\section{Determination of NsBr in FI system}

In FIA, amostigmine solutions of different concentrations were injected to the optimized FIA system. The peak heights were measured, and then compared to those obtained from injecting standard solutions of pure drug.

\section{Content uniformity assay of neostigmine tablets}

Ten individual tablets were placed in separate $100 \mathrm{ml}$ beaker and dissolved in $90-100 \mathrm{ml}$ of distilled water. Concentration of the solutions was determined by the standard addition method, as described above.

\section{Dissolution test}

The test was carried out according to the USP XXXII method apparatus II [18]. One tablet $(15 \mathrm{mg})$ was placed in the vessel, and the dissolution medium ( $900 \mathrm{ml} 1.0 \times 10^{-2} \mathrm{M}$ hydrochloric acid) was maintained at $37 \pm 0.5^{\circ} \mathrm{C}$. The vessel was rotated at $50 \mathrm{rpm}$. For the potentiometric determination, after an appropriate time interval (0.5-5 $\mathrm{min})$, the potential values were recorded, and the amount of the neostigminewas calculated from the calibration graph. For the spectrophotometric measurements, $5.0 \mathrm{ml}$ aliquots of the dissolution solution were withdrawn, filtered, diluted with $0.01 \mathrm{M} \mathrm{HCl}$ and the absorbance was measured at $261 \mathrm{~nm}$. A calibration graph was used for drug release calculation. In order to investigate all the important physical processes during the dissolution period, the release profiles were numerically simulated by a typical equation.

\section{Results and Discussion}

\section{Composition of the coating membrane}

Twenty CW membranes sensors of the different compositions of varying nature and ratios of ion-exchanger/PVC/plasticizer were prepared and investigated to coat several conductive beds as given in Table 2. CWSs made by using coating solution exhibited a calibration plot of Nernstain slope ranged from (57.0- 61.5) $\mathrm{mV}$ per concentration decade, at $25^{\circ} \mathrm{C}$,) over a wide concentration range $\left(5.0 \times 10^{-7}-1.0 \times 10^{-2} \mathrm{M}\right)$ with a detection limit of range $\left(4.0 \times 10^{-8}-7.910^{-8}\right) \mathrm{M}$ as shown in Figure 2.

For FIA measurements, a series of freshly prepared solutions of the drug covering the range $1.0 \times 10^{-7}-1.0 \times 10^{-1} \mathrm{M}$ was injected to the flow stream and the corresponding peak heights were recorded and used to draw the calibration graphs.

\section{Effect of soaking and lifetime of the sensor}

The performance characteristics of the $\mathrm{NsBr}$ CWEs were studied as a function of soaking time. For this purpose, the sensors were soaked in $1 \times 10^{-3} \mathrm{M}$ solution of $\mathrm{NsBr}$ and the calibration graphs $\left(\mathrm{E}_{\text {elec }}\right.$ $\mathrm{mV}$ vs, pNsBr) were plotted after 30 min until reaches to one month. The optimum soaking time was found as in Table 2. Kept the sensors dry in an opaque closed vessel and stored in a refrigerator while not in use. The reproducibility of five repeated measurements on the same solution was $\pm 1 \mathrm{mV}$. The calibration plot slopes decreased slightly after 

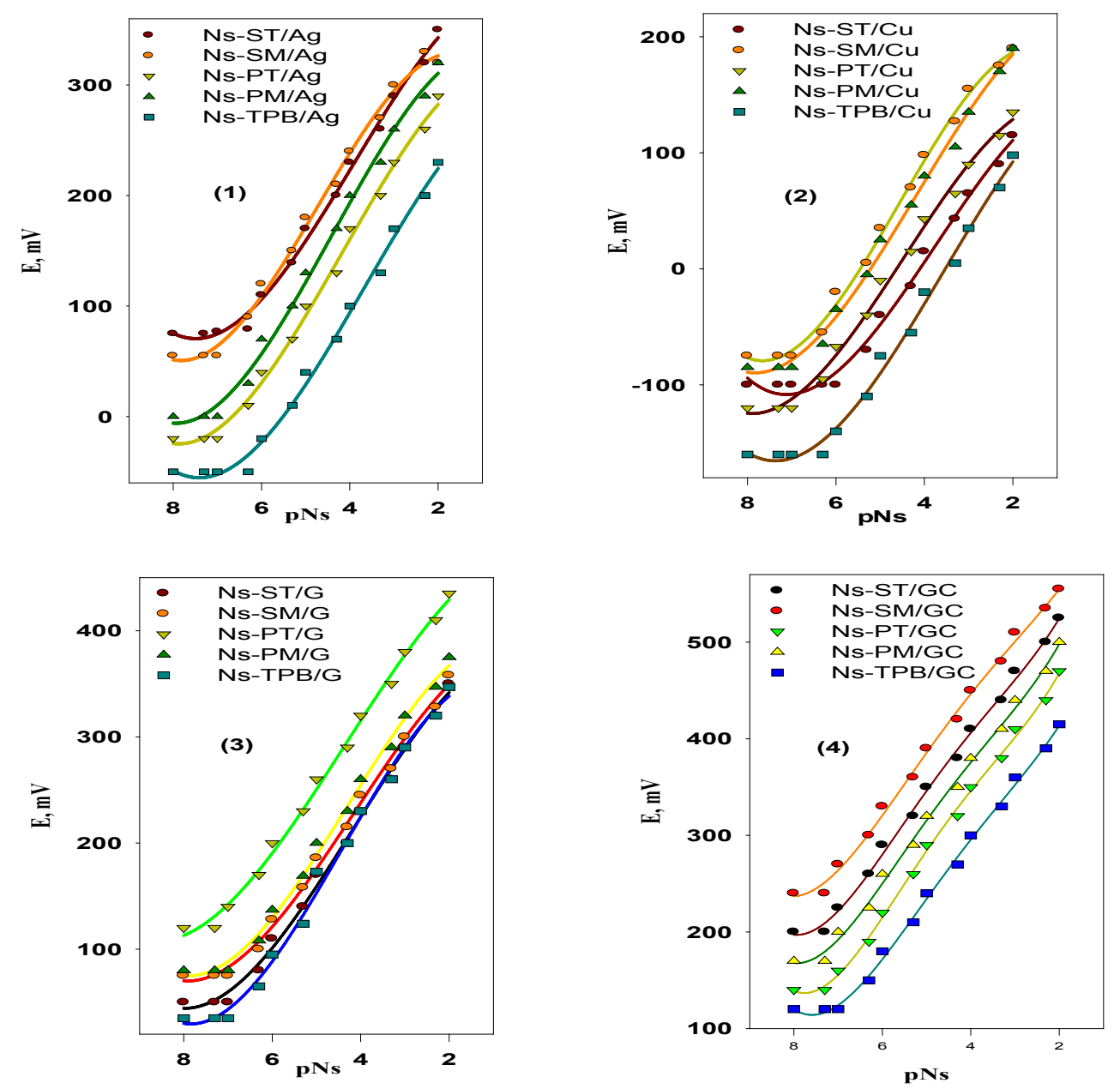

Figure 2: Calibration graphs for coated wires sensors Ns/Ag (1), Ns/Cu (2),Ns/G (3) and Ns/GC (4).

\begin{tabular}{|c|c|c|c|c|c|c|}
\hline \multicolumn{5}{|c|}{ FIA conditions } & \multicolumn{2}{|c|}{ Sensor characteristics } \\
\hline & $V_{\text {inj }}$ & $\mathrm{F}_{\mathrm{m}}$ & & S & & $\left(\mathrm{t}_{\text {resp }}\right)$, \\
\hline Sensors & $(\mu \mathrm{L})$ & $(\mathrm{mL} / \mathrm{mim})$ & Linear range $(\mathrm{M})$ & (mV/decade) & LOD & (s) \\
\hline \multicolumn{7}{|c|}{ Coated wires } \\
\hline Ns-ST/Ag & 75 & 12.5 & $5.0 \times 10^{-6}-5.0 \times 10^{-2}$ & $61.5 \pm 1.5$ & $7.5 \times 10^{-7}$ & $\leq 12$ \\
\hline $\mathrm{Ns}-\mathrm{SM} / \mathrm{Cu}$ & 75 & 12.5 & $1.0 \times 10^{-5}-1.0 \times 10^{-2}$ & $60.5 \pm 1.0$ & $8.7 \times 10^{-6}$ & $\leq 15$ \\
\hline Ns-PT/G & 75 & 12.5 & $2.5 \times 10^{-6}-1.2 \times 10^{-2}$ & $62.5 \pm 2.0$ & $6.5 \times 10^{-7}$ & $\leq 20$ \\
\hline Ns-PM/GC & 75 & 12.5 & $1.0 \times 10^{-6}-1.0 \times 10^{-2}$ & $63.5 \pm 2.0$ & $3.9 \times 10^{-7}$ & $\leq 25$ \\
\hline
\end{tabular}

\footnotetext{
$\mathrm{V}_{\text {inj: }}$ Injection volume $(\mu \mathrm{l})$.

$\mathrm{F}_{\mathrm{m}}$ : Flow rate $(\mathrm{mL} / \mathrm{min})$

LOD: Limit of detection

$\mathrm{t}_{\text {ress: }}$ : response time (s) in $\mathrm{Fl}$ analysis.
}

Table 3: Optimized FIA conditions and the response characteristics of the sensors.

the first week and continued to decrease reaching to one month. This is due to leaching, through minimal, of the electro active species into the bathing solution. The slope of the calibration graph obtained by the CW sensors was found to decrease slightly after several times of use, which may be attributed to surface contaminations.

\section{Optimization of the FIA response}

The parameters of all optimization factors for FIA responsibility were discussed carefully as in a supplementary file of biosensor and bioelectronics journal for determine neostigmine bromide [6] and the results for CW sensors were collected and given in Table 3 and Figure 3.

\section{Effect of pH}

The $\mathrm{pH}$ effect for the $\mathrm{NsBr}$ solution $\left(10^{-5}, 10^{-4}, 10^{-3} \mathrm{M} \mathrm{NsBr}\right)$ on the sensors potentials was investigated. The $\mathrm{NsBr}$ solution was acidified by the addition of very small volumes of $\mathrm{HCl}$ then the $\mathrm{pH}$ value was increased gradually using $\mathrm{NaOH}(0.1$ or $1.0 \mathrm{M})$. For each $\mathrm{pH}$ value, the potential was recorded and thus the potential-pH curves for three concentrations were constructed in Figure 4. As is obvious, within the 

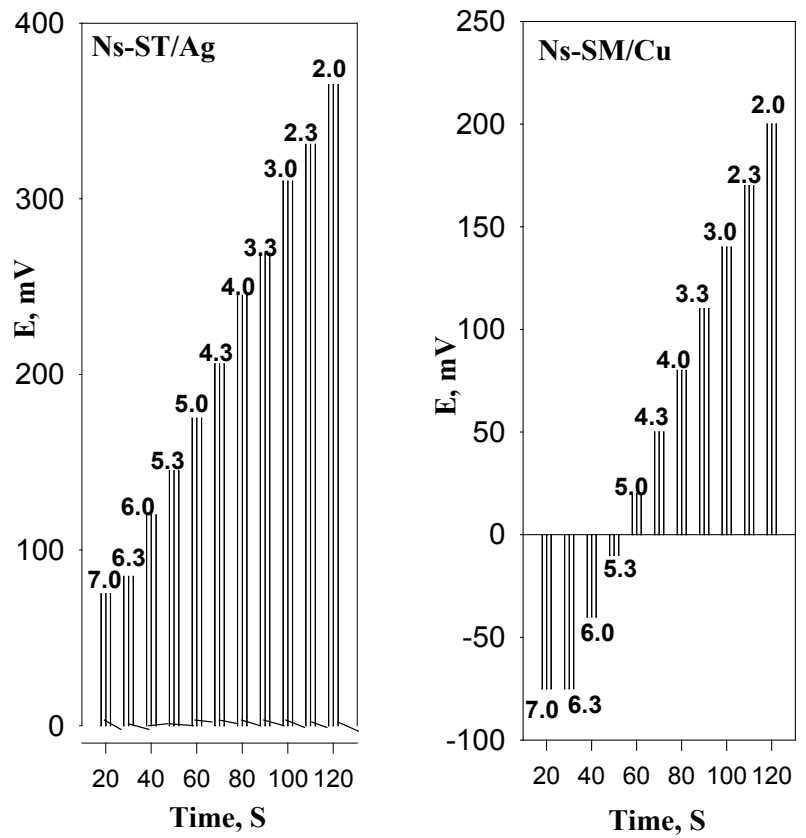
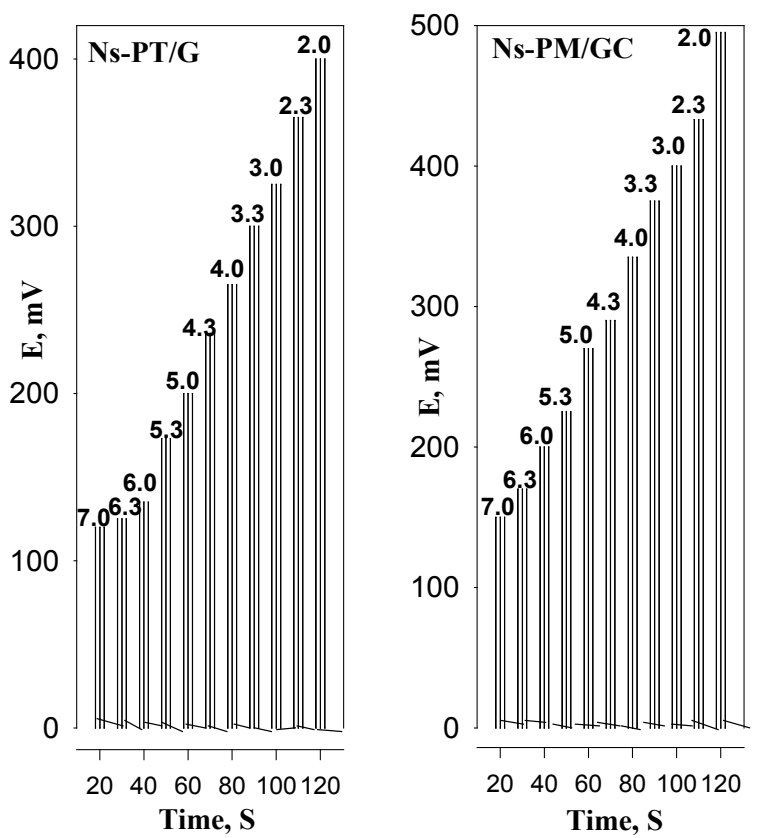

Figure 3: The FIA recordings obtained with Ns-CWs at optimum conditions.

pH range 4.0-11.0, the CW sensors potential are practically independent of $\mathrm{pH}$, and in this range, the sensors can be safely used for neostigmine determination. The increase in $\mathrm{mV}$ readings at $\mathrm{pH}$ less than 4.0 may be due to penetration of $\mathrm{H}^{+}$into the membrane surface or a gradual increase of protonated species dependence of the emf on the $\mathrm{pH}$ of the solution.

At higher $\mathrm{pH}$ values, free base precipitates in the test solution and consequently, the concentration of unprotonated species gradually increased. As a result, lower emf readings were recorded.

\section{Selectivity of the sensor}

Many species were determined by the matched potential for the selectivity. The inorganic cations do not interfere because of differences in ionic size, mobility and permeability. In FI conditions, the values of selectivity coefficients were calculated based on potential values measured at the tops of the peaks for the same concentrations of the $\mathrm{NsBr}$ and the interferents according to the separate solution method [17].

The resulting values are listed in Table 4 . Most of the interfering ions show values of selectivity coefficient low, indicating negligible interference in the performance of the CW sensor assembly. By comparing the selectivity coefficients values obtained for the sensors under investigation both in steady state and FI conditions Table 4, it is recording that there are some differences between the values both in steady state and FI, for each interfering ion. The difference may be attributed to the applied different methods where the matched potential in steady state and separate solution methods in FI respectively. The interpretation by difference in time of interaction of interferons with the sensor in comparison to the main sensed ion where the rate of diffusion and the exchange reaction of the interfering ion are also the reasons for interference process.

\section{Analytical application}

The analytical applications of $\mathrm{CW}$ sensors investigated the determination of the Ns in its pure solution, pharmaceutical dosage forms, and human urine by the calibration curve, standard addition method and potentiometric titration which are the most widely and applied in analytical application. The data reflect the high degree of validation for accuracy, precision, and a wide concentration range of the drug. Also, the response times are instant so the CW sensors are very rapidly transferred forth and back between the biological human samples and washed by the bi-distilled water between measurements to protect the sensing component from adhering to the surface of some matrix components. As shown in Table 5.

In FIA conditions, by comparison the peak heights which is the best method used for the determination of Ns in its bulk powder or pharmaceutical dosage form, where the peaks obtained from a series of different concentrations of the Ns is compared with those obtained by injecting a standard series of the Ns measured under the same conditions of sample volume, flow rate, temperature and $\mathrm{pH}$.

\section{Validation of the proposed method}

Linearity and detection limit (LOD): The value of LOD for the proposed method is the sensitive for detection of very small concentrations of Ns with the optimal experimental CW sensors conditions with a linear relationship exists between the sensor potential $/ \mathrm{mV}$ and the logarithm of corresponding concentration of the Ns drug.

Accuracy: The accuracy was investigated by the determination of $\mathrm{NsBr}$ in its pharmaceutical preparations without interfering of the proposed CWS methods from the co formulated adjuvant as indicated by the mean recoveries value as shown in Table 5 .

Precision: The precision was measured as the percentage of relative standard deviation (\% RDS) and was tested by repeating the proposed CWS method for analysis of the investigated NsBr in intraday (within the day) and inter-day (consecutive days) to five replicates. The obtained \% RSD as shown in Table 5 and the values are less than $2 \%$, indicating good precision. 
Citation: Khorshid AF, Issa YM (2015) Novel Coated Wires Sensors with Flow-Injection for Potentiometric Determination of Neostigmine in Bulk, Amostigmine and Human Urine. J Bioequiv Availab 7: 131-139. doi:10.4172/jbb.1000227

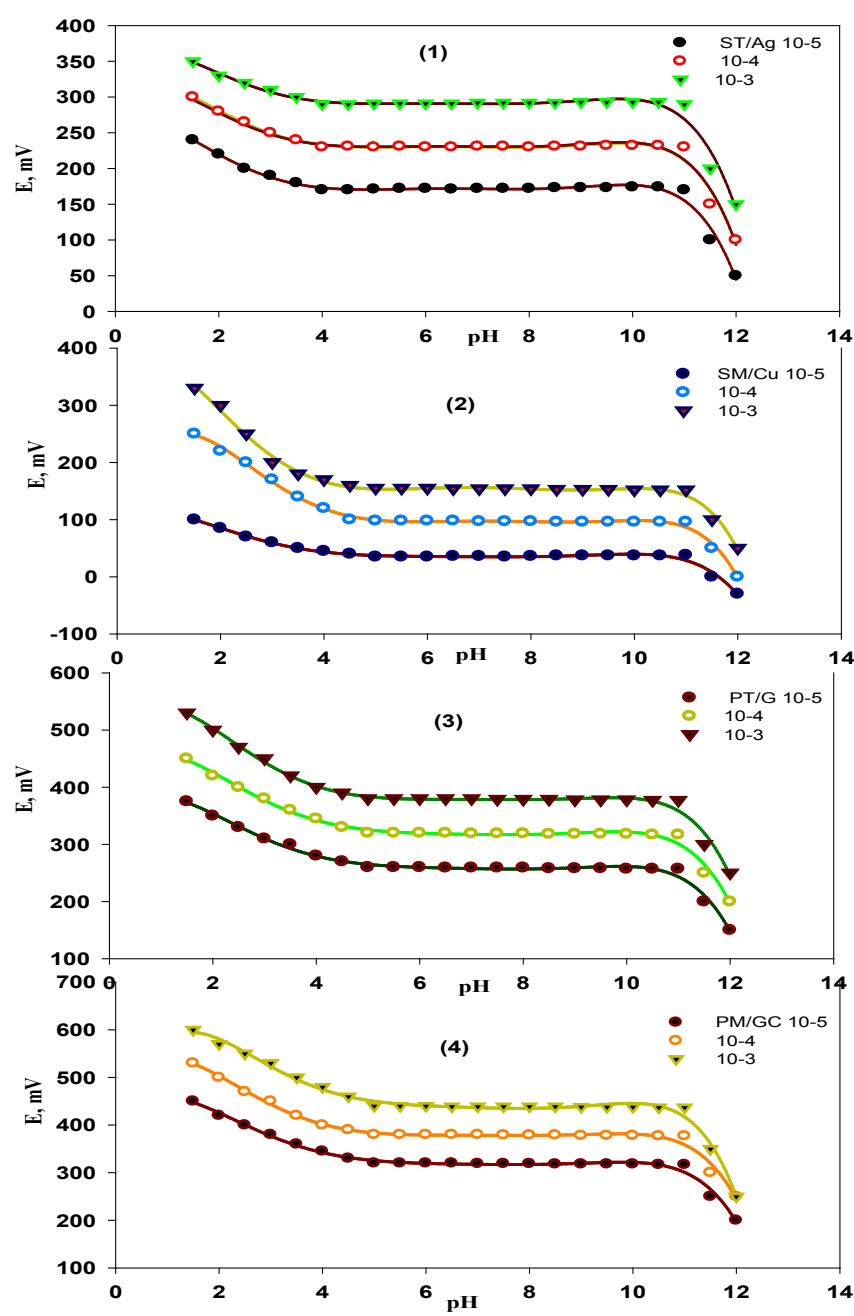

Figure 4: Effect of pH of the test solution (1) ST/Ag, (2) SM/Cu, (3) PT/G and (4) $P M / G C$.

Robustness and ruggedness: The robustness method was examined by the replacement of aqueous solution by another $\mathrm{pH}$ value for the Ns-CWs. The results are in a good agreement with those obtained from standard drug solution in another media ranging from 4-11. In addition, the ruggedness was showed by using another type of the potential readings as $\mathrm{pH}$-meter model (Jenway, 3510) for each CW sensor.

Reproducibility of the sensor: The repeatability is the examination of the potential reading for the Ns-CWS sensors by the subsequent measurements in $1.0 \times 10^{-3} \mathrm{M} \mathrm{NsBr}$ solution then followed by measuring the first set of solution at $1.0 \times 10^{-4} \mathrm{M} \mathrm{NsBr}$. The standard deviation values for each type of sensor are given in Table 6 by measuring emf for five replicate measurements. The values indicate the excellent repeatability of the potential response of the sensors.

Content uniformity of amostigmine tablets: The content uniformity assay for determination of amostigmine tablets by Ns-CWS methods described good accuracy, precision and reproducible results for the quality control tests so the sensors can be working for the quantification determination of neostigmine ions and the percentage of the recoveries of $\mathrm{NsBr}$ is mainly in acceptance quantitatively.

\section{Potentiometric monitoring of neostigmine tablet dissolution}

The changes in the electrochemical potential readings for the dissolution medium caused by the dissolving amostigmine tablet $15 \mathrm{mg} /$ tablet can be detecting by the CW sensor monitors to the dissolution of the tablet. These changes of potential are converted into the concentration in $\%$ of dissolved Ns drug release via dedicated ("Potential measured in $\mathrm{mV}$, to Concentration"). The results are comparison with subsequent another sample analysis using UV spectrophotometric. The releases shows that immediately ruptured of Ns tablet. Taking into account that the releasing was achieved the first during 15 min nearly $50 \%$ was released, followed by the second more than $74 \%$ drug was released according to USP [18].

For the UV spectrophotometric assay, the dissolution medium were diluted with $0.01 \mathrm{M} \mathrm{HCl}$, measured at $\lambda_{\max } 261 \mathrm{~nm}$ and compared with a calibration graph. Figure 5 shows the dissolution profiles of neostigmine tablet using both measurement techniques. The spectrophotometric and potentiometry are almost identical results but the use of the potentiometric method sensor, however, has the advantage of more sensitive due to overcome the matrix effect.

\section{Statistical treatment of results}

The recoveries of the results for the determination of Ns drug by applying the calibration curve, standard additions method and the potentiometric titration were evaluated statistically and were

\begin{tabular}{|c|c|c|c|c|c|}
\hline Interferent & Ns-ST/Ag & $\mathrm{Ns}-\mathrm{SM} / \mathrm{Cu}$ & Ns-PT/G & $\begin{array}{c}\text { Ns-PM/ } \\
\text { GC }\end{array}$ & $\begin{array}{c}\text { Ns-ST/Ag } \\
(\mathrm{FIA})\end{array}$ \\
\hline $\mathrm{Na}^{+}$ & 3.45 & 3.34 & 3.28 & 3.28 & 2.5 \\
\hline $\mathrm{K}^{+}$ & 3.61 & 3.47 & 3.33 & 3.56 & 2.9 \\
\hline $\mathrm{Ca}^{2+}$ & 3.75 & 3.67 & 3.55 & 3.53 & 2.7 \\
\hline $\mathrm{Mg}^{2+}$ & 3.77 & 3.45 & 3.36 & 3.45 & 2.7 \\
\hline $\mathrm{NH}_{4}^{+}$ & 3.94 & 3.72 & 3.49 & 3.62 & 2.4 \\
\hline $\mathrm{Ba}^{2+}$ & 3.88 & 3.41 & 3.64 & 3.70 & 3.0 \\
\hline $\mathrm{Mn}^{2+}$ & 3.86 & 3.76 & 3.47 & 3.51 & 3.0 \\
\hline $\mathrm{Cu}^{2+}$ & 3.79 & 3.71 & 3.56 & 3.80 & 3.4 \\
\hline $\mathrm{Cd}^{2+}$ & 3.74 & 3.54 & 3.36 & 3.63 & 3.3 \\
\hline $\mathrm{Pb}^{2+}$ & 3.96 & 3.90 & 3.87 & 3.78 & 3.2 \\
\hline Sr2+ & 3.92 & 3.74 & 3.67 & 3.98 & 3.3 \\
\hline Cr3+ & 3.98 & 3.57 & 3.79 & 3.78 & 3.6 \\
\hline $\mathrm{Al} 3+$ & 3.86 & 3.72 & 3.69 & 3.77 & 3.5 \\
\hline Glucose & 4.32 & 4.26 & 4.19 & 4.06 & -- \\
\hline Lactose & 4.27 & 4.20 & 4.17 & 4.20 & -- \\
\hline Fructose & 4.26 & 4.17 & 4.15 & 4.11 & -- \\
\hline Maltose & 4.31 & 4.26 & 4.29 & 4.18 & -- \\
\hline Urea & 3.76 & 3.59 & 3.47 & 3.55 & -- \\
\hline Vit. C & 4.41 & 4.39 & 4.19 & 4.39 & -- \\
\hline Thiamine $\mathrm{HCl}$ & 3.63 & 3.73 & 3.44 & 3.43 & -- \\
\hline Pyridoxine $\mathrm{HCl}$ & 3.95 & 3.87 & 3.85 & 3.14 & -- \\
\hline Folic acid & 3.40 & 3.55 & 3.42 & 3.33 & -- \\
\hline Citric acid & 3.93 & 3.82 & 3.74 & 3.67 & -- \\
\hline Theronin & 4.33 & 4.43 & 4.27 & 4.32 & -- \\
\hline L-valine & 4.41 & 4.59 & 4.61 & 4.25 & -- \\
\hline L-lysine $\mathrm{HCl}$ & 3.65 & 3.43 & 3.87 & 3.64 & -- \\
\hline Asparagine & 4.33 & 4.26 & 4.18 & 4.27 & -- \\
\hline L-arginine & 4.31 & 4.22 & 4.21 & 4.24 & -- \\
\hline Glutamic acid & 4.35 & 4.27 & 4.23 & 4.13 & -- \\
\hline
\end{tabular}

Table 4.Selectivity coefficient values $(-\log K)$ forNs- CW sensors. Ns. $J^{z+}$ 
Citation: Khorshid AF, Issa YM (2015) Novel Coated Wires Sensors with Flow-Injection for Potentiometric Determination of Neostigmine in Bulk, Amostigmine and Human Urine. J Bioequiv Availab 7: 131-139. doi:10.4172/jbb.1000227

\begin{tabular}{|c|c|c|c|c|c|c|c|c|c|}
\hline CW & & $\mathbf{A g}$ & & $\mathrm{Cu}$ & & $\mathbf{G}$ & & GC & \\
\hline \multirow{2}{*}{ Sensors } & Taken & Recovery & RSD & Recovery & RSD & Recovery & RSD & Recovery & RSD \\
\hline & $\mathrm{mg}$ & (\%) & $(\%)$ & (\%) & $(\%)$ & (\%) & $(\%)$ & (\%) & (\%) \\
\hline
\end{tabular}

Standard addition method

Pure solutions

\begin{tabular}{|c|c|c|c|c|c|c|c|c|c|}
\hline \multirow[t]{3}{*}{ Ns-ST } & 1.52 & 99.9 & 0.33 & 98.9 & 0.41 & 99.3 & 0.51 & 99.6 & 0.18 \\
\hline & 3.03 & 99.8 & 0.25 & 99 & 0.29 & 99.7 & 0.35 & 99.8 & 0.32 \\
\hline & 4.55 & 99.6 & 0.13 & 98.7 & 0.37 & 99.4 & 0.44 & 99.6 & 0.39 \\
\hline \multirow[t]{3}{*}{ Ns-SM } & 1.52 & 99.2 & 0.51 & 98.9 & 0.61 & 99.5 & 0.28 & 99.8 & 0.55 \\
\hline & 3.03 & 99.1 & 0.4 & 98.7 & 0.37 & 99.3 & 0.43 & 99.7 & 0.71 \\
\hline & 4.55 & 99 & 0.36 & 98 & 0.64 & 99 & 0.37 & 99.5 & 0.54 \\
\hline \multirow[t]{3}{*}{ Ds-PT } & 1.52 & 99.5 & 0.23 & 98.7 & 0.33 & 99.6 & 0.41 & 99.4 & 0.4 \\
\hline & 3.03 & 99.3 & 0.37 & 98.6 & 0.5 & 98.5 & 0.6 & 99.6 & 0.27 \\
\hline & 4.55 & 99.7 & 0.28 & 98.3 & 0.48 & 99.1 & 0.38 & 99.3 & 0.3 \\
\hline \multirow[t]{3}{*}{ Ds-PM } & 1.52 & 99.1 & 0.57 & 98.3 & 0.26 & 99 & 0.6 & 99.5 & 0.46 \\
\hline & 3.03 & 99.4 & 0.35 & 99.1 & 0.33 & 99.1 & 0.68 & 99.6 & 0.7 \\
\hline & 4.55 & 99.2 & 0.39 & 98.5 & 0.54 & 99.3 & 0.58 & 99.4 & 0.53 \\
\hline \multirow[t]{3}{*}{ Ds-TPB } & 1.52 & 99.4 & 0.36 & 98.8 & 0.53 & 99.3 & 0.43 & 99 & 0.81 \\
\hline & 3.03 & 99.3 & 0.55 & 98.4 & 0.38 & 99.7 & 0.56 & 99.3 & 0.77 \\
\hline & 4.55 & 99.q & 0.47 & 98.7 & 0.27 & 99.3 & 0.39 & 99.1 & 0.22 \\
\hline \multicolumn{10}{|c|}{ Amostigmine tablet (15 mg/tablet) Ns-ST } \\
\hline & 1.52 & 99.2 & 0.53 & 102.7 & 0.63 & 99.4 & 0.76 & 99.3 & 0.52 \\
\hline & 3.03 & 101.2 & 0.48 & 102.9 & 0.39 & 100.5 & 0.58 & 99 & 0.63 \\
\hline & 4.55 & 99 & 0.36 & 99 & 0.26 & 100.8 & 0.37 & 100.7 & 0.39 \\
\hline & 6.06 & 102 & 0.78 & 101.7 & 0.31 & 101.3 & 0.56 & 101.2 & 0.6 \\
\hline \multicolumn{10}{|c|}{ Amostigmine injection $(0.5 \mathrm{mg} / \mathrm{ml}) \mathrm{Ns}-\mathrm{ST}$} \\
\hline & 1.52 & 99.8 & 0.32 & 96.2 & 0.31 & 99.3 & 0.55 & 99.7 & 0.56 \\
\hline & 3.03 & 99.5 & 0.57 & 99.6 & 0.25 & 99.9 & 0.49 & 99.6 & 0.77 \\
\hline & 4.55 & 99.6 & 0.32 & 99.5 & 0.67 & 99.7 & 0.52 & 99.6 & 0.58 \\
\hline & 6.06 & 99.1 & 0.72 & 99.1 & 0.43 & 99.4 & 0.63 & 99.3 & 0.71 \\
\hline \multicolumn{10}{|c|}{ Spiked Urine Ns-ST } \\
\hline & 1.52 & 98.6 & 0.22 & 98 & 0.33 & 99 & 0.5 & 99.1 & 0.35 \\
\hline & 3.03 & 98.7 & 0.41 & 98.4 & 0.5 & 99 & 0.62 & 99.3 & 0.6 \\
\hline & 4.55 & 98.3 & 0.46 & 98.1 & 0.56 & 99 & 0.32 & 99 & 0.34 \\
\hline \multicolumn{10}{|c|}{ Potentiometric titration: (Ns-ST) as ion-association and as titrant: } \\
\hline \multirow[t]{6}{*}{ Pure solutions } & 3.03 & 100.9 & 0.19 & 102.2 & 0.11 & 100.7 & 0.33 & 101.1 & 0.13 \\
\hline & 6.06 & 101.3 & 0.22 & 102.5 & 0.31 & 100.3 & 0.21 & 101.5 & 0.22 \\
\hline & 9.09 & 101.5 & 0.26 & 102 & 0.33 & 100.5 & 0.14 & 100.9 & 0.61 \\
\hline & 15.16 & 101.5 & 0.2 & 102.4 & 0.5 & 100.6 & 0.17 & 101.4 & 0.18 \\
\hline & 21.22 & 101.7 & 0.44 & 102.5 & 0.46 & 100.7 & 0.33 & 101.7 & 0.24 \\
\hline & 30.32 & 100.9 & 0.51 & 102.2 & 0.37 & 100.9 & 0.41 & 101.9 & 0.26 \\
\hline \multicolumn{10}{|c|}{ Amostigmine tablet (15 mg/tablet) } \\
\hline & 3.03 & 102 & 0.17 & 102.4 & 0.1 & 101.1 & 0.21 & 101 & 0.41 \\
\hline & 9.09 & 102.2 & 0.19 & 102.6 & 0.15 & 101.6 & 0.31 & 101.2 & 0.23 \\
\hline & 15.16 & 102.3 & 0.1 & 102.7 & 0.17 & 101.7 & 0.14 & 101.5 & 0.36 \\
\hline & 21.22 & 102.5 & 0.12 & 102.7 & 0.23 & 101.9 & 0.11 & 101.8 & 0.44 \\
\hline \multicolumn{10}{|c|}{ Amostigmine injection $(0.5 \mathrm{mg} / \mathrm{ml})$} \\
\hline & 3.03 & 99.8 & 0.22 & 99 & 0.27 & 99.3 & 0.33 & 99.8 & 0.15 \\
\hline & 9.09 & 99.7 & 0.52 & 99.1 & 0.23 & 99.6 & 0.25 & 99.5 & 0.11 \\
\hline & 15.16 & 99.3 & 0.36 & 99 & 0.25 & 99.5 & 0.42 & 99.2 & 0.18 \\
\hline & 21.22 & 99 & 0.41 & 99.1 & 0.21 & 99.7 & 0.27 & 99.4 & 0.25 \\
\hline
\end{tabular}

Table 5: Determination of neostigmine in pure solutions, amostigmine tablet (15 mg/tablet), amostigmine injection ( $0.5 \mathrm{mg} / \mathrm{ml})$ and urine by the employing the coated wires sensors applying the standard addition method and potentiometric titration.

compared to those values obtained with the (Official) pharmacopeia method by applying the F-tests [19,20]. The values were obtained Table 7 show that the CWS determination methods have a precision comparable to that of the pharmacopeia method. However, the CWS methods are more practical regarding consumption of solvents, time of analysis, and sample pretreatment requirements for official analysis of neostigmine bromide.

\section{Conclusion}

Some important advantages for the proposed method have: The proposed potentiometric methods based on the construction of different selective CW sensors with ion exchangers in analytical characteristics for the determination of $\mathrm{NsBr}$ proved to be complete successfully a rapid, simple and low cost potentiometric method for 
Citation: Khorshid AF, Issa YM (2015) Novel Coated Wires Sensors with Flow-Injection for Potentiometric Determination of Neostigmine in Bulk, Amostigmine and Human Urine. J Bioequiv Availab 7: 131-139. doi:10.4172/jbb.1000227

\begin{tabular}{|c|c|c|}
\hline Sensors & \multicolumn{2}{|c|}{ Standard deviation S.D } \\
\hline Ns- CW Sensors & $1.0 \times 10^{-4}$ & $1.0 \times 10^{-3}$ \\
\hline$(1) \mathrm{Ns} / \mathrm{Ag}$ & 0.55 & 0.64 \\
\hline$(2) \mathrm{Ns} / \mathrm{Cu}$ & 0.73 & 0.88 \\
\hline$(3) \mathrm{Ns} / \mathrm{G}$ & 0.48 & 0.76 \\
\hline$(4) \mathrm{Ns} / \mathrm{GC}$ & 0.45 & 0.59 \\
\hline
\end{tabular}

Table 6: The standard deviation values of measuring emf for five replicate measurements obtained for each CW sensor.

the determination of $\mathrm{NsBr}$ in bulk solutions and in pharmaceutical preparations: it ensures a good for the neostigmine assay due to the possibility to control the ion activity continuously and also a fast assay of Amostigmine tablets. The excellent recoveries and low relative standard deviations obtained reflect the high accuracy and precision of the proposed method. In addition, the method is easy to operate, high sensitivity, simple, fast static response; reasonable selectivity; long term stability and applicability over a wide concentration range.

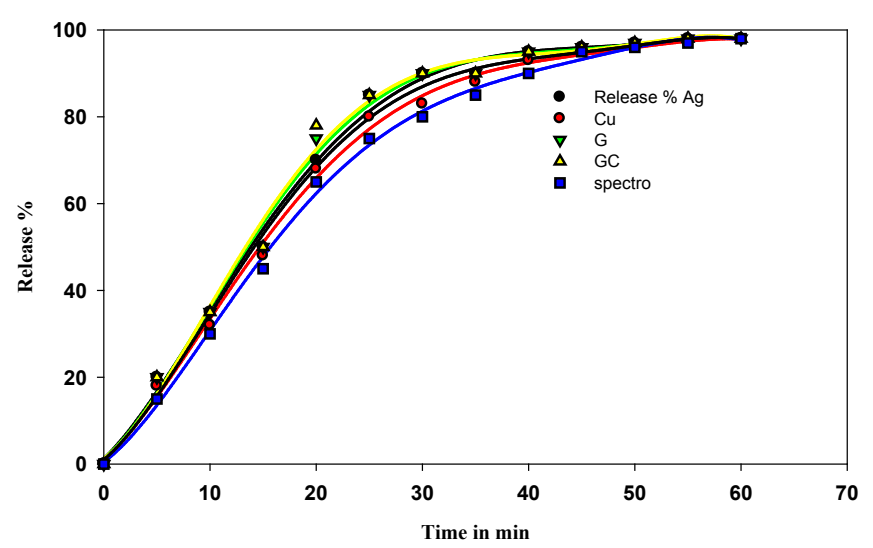

Figure 5: Dissolution profile $15 \mathrm{mg}$ neostigmine tablet obtained by $\mathrm{Ag}, \mathrm{Cu}, \mathrm{G}$ and GC with spectrophotometric measurement at $261 \mathrm{~nm}$.

\begin{tabular}{|c|c|c|c|c|c|c|}
\hline \multirow{2}{*}{\multicolumn{2}{|c|}{$\begin{array}{l}\text { Sample Official method } \\
\text { Pure solutions }\end{array}$}} & \multicolumn{5}{|c|}{ Standard addition method } \\
\hline & & \multirow{2}{*}{$\begin{array}{l}\mathbf{A g} \\
99.7 \pm 0.5\end{array}$} & \multirow{2}{*}{$\begin{array}{l}\text { Cu } \\
98.5 \pm 0.5\end{array}$} & \multirow{2}{*}{\begin{tabular}{|l|} 
G \\
$99.2 \pm 0.5$
\end{tabular}} & \multirow{2}{*}{\begin{tabular}{|l|} 
GC \\
$99.6 \pm 0.6$
\end{tabular}} & \multirow{2}{*}{$\begin{array}{l}\text { Ns-ST/Ag (FIA) } \\
99.2 \pm 0.5\end{array}$} \\
\hline$X \pm$ S.E. & $99.8 \pm 0.2$ & & & & & \\
\hline F value & & 1.75 & 2.61 & 2.15 & 2.45 & 2.55 \\
\hline $\mathrm{t}$ value & & 2.47 & 2.33 & 1.84 & 2.22 & 1.65 \\
\hline \multicolumn{7}{|c|}{ Amostigmine tablets (15 mg/tablet) } \\
\hline $\mathrm{X} \pm$ S.E. & $101.3 \pm 0.2$ & $101.0 \pm 0.5$ & $102.0 \pm 0.5$ & $101.5 \pm 0.5$ & $101.0 \pm 0.5$ & $102.5 \pm 0.5$ \\
\hline F value & & 2.42 & 2.33 & 2.65 & 2.18 & 2.56 \\
\hline $\mathrm{t}$ value & & 1.36 & 2.16 & 1.46 & 1.69 & 1.35 \\
\hline \multicolumn{7}{|c|}{ Amostigmine injection $(0.5 \mathrm{mg} / \mathrm{mL})$} \\
\hline $\mathrm{X} \pm$ S.E. & $99.6 \pm 0.07$ & $99.5 \pm 0.5$ & $98.5 \pm 0.5$ & $99.5 \pm 0.5$ & $99.5 \pm 0.5$ & $101.5 \pm 0.5$ \\
\hline F value & & 2.76 & 2.78 & 2.45 & 2.55 & 2.45 \\
\hline t value & & 1.86 & 1.97 & 1.87 & 1.37 & 1.22 \\
\hline \multicolumn{7}{|c|}{ Spiked Urine } \\
\hline$X \pm S . E$ & $99.6 \pm 0.07$ & $99.0 \pm 0.5$ & $98.0 \pm 0.5$ & $99.0 \pm 0.5$ & $99.5 \pm 0.5$ & $102.0 \pm 0.5$ \\
\hline F value & & 2.73 & 2.62 & 2.92 & 4.11 & 2.61 \\
\hline $\mathrm{t}$ value & & 1.87 & 1.54 & 2.11 & 3.27 & 1.77 \\
\hline Sample & Official method & \multicolumn{5}{|c|}{ Potentiometric titration } \\
\hline Pure sol & & Ag & $\mathrm{Cu}$ & G & GC & Ns-ST/Ag (FIA) \\
\hline$X \pm S . E$. & $99.8 \pm 0.2$ & $99.5 \pm 0.5$ & $98.5 \pm 0.5$ & $99.5 \pm 0.5$ & $99.5 \pm 0.5$ & $100.5 \pm 0.5$ \\
\hline F value & & 2.42 & 2.22 & 2.26 & 2.33 & 2.04 \\
\hline $\mathrm{t}$ value & & 1.52 & 1.14 & 1.56 & 1.52 & 1.93 \\
\hline \multicolumn{7}{|c|}{ Amostigmine tablets (15 mg/tablet) } \\
\hline $\mathrm{X} \pm$ S.E. & $100.3 \pm 0.2$ & $101.5 \pm 0.5$ & $102.0 \pm 0.5$ & $101.5 \pm 0.5$ & $101.5 \pm 0.5$ & $101.5 \pm 0.09$ \\
\hline F value & & 2.54 & 2.96 & 2.56 & 2.41 & 2.33 \\
\hline $\mathrm{t}$ value & & 1.84 & 1.44 & 1.87 & 1.85 & 1.70 \\
\hline \multicolumn{7}{|c|}{ Amostigmine injection $(0.5 \mathrm{mg} / \mathrm{mL})$} \\
\hline$X \pm S . E$ & $99.8 \pm 0.06$ & $100.5 \pm 0.5$ & $101.5 \pm 0.5$ & $101.0 \pm 0.5$ & $101.5 \pm 0.5$ & $101.5 \pm 0.5$ \\
\hline F value & & 2.90 & 2.88 & 2.48 & 2.34 & 2.71 \\
\hline $\mathrm{t}$ value & & 1.25 & 1.96 & 1.66 & 1.15 & 1.09 \\
\hline
\end{tabular}

$\mathrm{X} \pm$ S.E.: Recovery \pm standard error.

F- tabulated is 6.39 at $95.0 \%$ confidence limit.

t- tabulated at $99.0 \%$ confidence limit and 6 degrees of freedom

Table 7: Statistical treatment of data obtained for the determination of neostigmine bromide applying the standard addition method and potentiometric titration using CW sensors in comparison with official methods. 
Citation: Khorshid AF, Issa YM (2015) Novel Coated Wires Sensors with Flow-Injection for Potentiometric Determination of Neostigmine in Bulk, Amostigmine and Human Urine. J Bioequiv Availab 7: 131-139. doi:10.4172/jbb.1000227

\section{References}

1. Sweetman SC (2007) Martindale: The Complete Drug Reference, $35^{\text {th }}(E d n)$. The Pharmaceutical Press, London.

2. (2005) Clarke's Analysis of Drugs and Poisons, $3^{\text {rd }}$ (Edn). The Pharmaceutical Press, London.

3. Gupta VK, Pal MK, Singh AK (2009) Development and applications of quaternary ammonium (QA) membrane electrodes in pharmaceutical preparation and in bioavailability of Prostaglandin E1 and Deoxycholate. ElectrochimActa 54: 6700-6706.

4. Issa YM, Khorshid AF (2011) Using PVC ion-selective electrodes for the potentiometric flow injection analysis of distigmine in its pharmaceutical formulation and biological fluids. J Advanced Research 2: 25-34.

5. El-Kosasy AM, Nebsen M, Abd El-Rahman MK, Salem MY, El-Bardicy MG (2011) Comparative study of 2-hydroxy propyl beta cyclodextrin and calixarene as ionophores in potentiometric ion-selective electrodes for neostigmine bromide. Talanta 85: 913-918.

6. Khorshid AF, Issa YM (2014) Modified carbon paste sensor for the potentiometric determination of neostigmine bromide in pharmaceutical formulations, human plasma and urine. Biosens Bioelectron 51: 143-149.

7. Ibrahim H, Issa YM, Abu Shawish HM (2005) Potentiometric flow injection analysis of drotaverine hydrochloride in pharmaceutical preparations. Anal Lett 38: 111-32.

8. Goyal RN, Gupta VK, Oyama M, Bachheti N (2007) Voltammetric determination of adenosine and guanosine using fullerene-C(60)-modified glassy carbon electrode. Talanta 71: 1110-1117.

9. Ibrahim $\mathrm{H}$ (2005) Carbon paste electrode modified with silver thimerosal for the potentiometric flow injection analysis of silver (I). Anal Chim Acta 545: 158-65.

10. Abdel Ghani NT, Issa YM, Ahmed HM (2006) Potentiometric flow injection analysis of bromhexine hydrochloride and its pharmaceutical preparation using conventional and coated wire ion-selective electrodes. Sci Pharm 74: 121-135.

11. Goyal RN, Gupta VK, Chatterjee S (2009) A sensitive voltammetric sensor for determination of synthetic corticosteroid triamcinolone, abused for doping. BiosensBioelectron 24: 3562-3568.

12. Goyal RN, Gupta VK, Chatterjee S (2008) Electrochemical oxidation of dideoxyadenosine at pyrolytic graphite electrode. ElectrochimActa 53: 535460.

13. Goyal RN, Gupta VK, Bachheti N, Sharma RA (2008) Electrochemical sensor for the determination of dopamine in presence of high concentration of ascorbic acid using a fullerene- $C_{60}$ coated gold electrode. Electroanalysis 20: 757-64.

14. Badawy SS, Issa YM, Mutair AA (2005) PVC membrane ion-selective electrodes for the determination of Hyoscyamine in pure solution and in pharmaceutical preparations under batch and flow modes. J Pharm Biomed Anal 39: 117-124.

15. Umezawa Y, Buhlmann P, Umezawa K, Tohda K, Amemiya S (2000) Potentiometric selectivity coefficients of ion-selective sensors. Part I. Inorganic cations (technical report). Pure Appl Chem 72: 1851-1855.

16. UmezawaY, Umezawa K, Sato H (1995) Selectivity coefficients for ion-selective sensors: recommended methods for reporting KA,B pot values (technical report). Pure Appl Chem 67: 507-511.

17. Guilbault G, Drust RA, Frant MS, Freiser H, Hansen, et al. (1976) Recommendations for nomenclature of ion-selective sensors. Pure Appl Chem 48 127-129.

18. United States Pharmacopeia (2009) National Formulary USP 32-NF 27 Convention, Inc.: Rockville, MD.

19. Skoog DA, Holler FJ, Neiman TA (1997) Principles of Instrumental Analysis, $5^{\text {th }}$ (Edn). Harcourt Brace College Publishers, London.

20. Miller JC, Miller JN (1994) Statistics for Analytical Chemistry. Ellis Horwood, Chichester, England 